\title{
Kessler adds heat to smoking debate
}

\author{
Washington. The head of the Food and Drug \\ Administration (FDA), David Kessler, has \\ told a congressional hearing that the to- \\ bacco industry may intentionally control the \\ levels of nicotine in its products in order to \\ create and sustain addiction in a majority of \\ smokers. He also revealed that at least one \\ tobacco company sponsored animal research \\ in the 1980s that showed that nicotine was \\ addictive. When the company learned that a \\ DOONESBURY
}

"numerous patents illustrate how the industry has been working to sustain the psychoactive effects of nicotine in cigarettes". But Alexander Spear, vice chairman of the Lorillard Tobacco Company, told the hearing that holding a patent does not mean that the invention is in use.

Major cigarette manufacturers declined to testify, but Charles Whitley, a consultant for the Tobacco Institute, the industry's

\section{IMAGE UNAVAILABLE FOR COPYRIGHT REASONS}

trade association, told the hearing that the tobacco companies do not manipulate nicotine levels in different types of tobacco leaf. He said that although nicotine is extracted during manufacture, no more is added to the actual product than is present originally. The Philip Morris Company made the point even more strongly on the day before the hearing by filing a $\$ 10$ billion lawsuit against $\mathrm{ABC}$ television, which alleged that the company spiked cigarettes with nicotine to keep people addicted.

Kessler admitted that the FDA does not yet have sufficient evidence to establish the motives of cigarette manufacturers. But the anti-smoking groups are optimistic that the attention generated both by his remarks and by congressional hearings will help to achieve their main aim - tough federal legislation restricting the use of cigarettes and reducing the health damage they cause

Helen Gavaghan

journal had accepted a paper on the topic from its scientists, it took out an injunction to prevent publication, he said. Kessler would not name the company.

The revelations came during a hearing before the health and environment subcommittee of the House of Representatives Committee on Energy and Commerce. Congressmen concentrated their fire on the key question of the manufacturers' intent, which is central to a fierce debate in the United States about whether the FDA can regulate tobacco products as drugs.

If there is an intention to create and meet an addiction, cigarettes can be regulated under the Food, Drug and Cosmetics Act of 1938 , on the grounds that they are intended to alter the structure or function of the body. As a result the tobacco industry would have to withdraw its products - cigarettes and smokeless tobacco - and submit them to FDA efficacy and safety tests before being allowed to market them again.

If, on the other hand, nicotine is in cigarettes simply because it is a natural constituent of tobacco, tobacco products would not be subject to regulation by the FDA.

The debate sprang to life last month with Kessler's response to a petition filed by antismoking groups (see Nature 368, 83; 1994) arguing that by marketing low-tar and lownicotine cigarettes, the tobacco industries were developing products intended to mitigate disease and that nicotine changes the structure and function of the body. Thus, cigarettes should be classed as a drug.

Kessler startled smoking and anti-smoking groups by saying that the petition might be right. Kessler cited the mounting evidence that nicotine is a powerfully addictive drug as well as evidence that the tobacco industry controls the levels of nicotine that satisfy this addiction.

In testimony last week, Kessler said that

\section{Quick solution demanded for Rutherford}

London. The British government is being urged to make a quick decision on the future of the two main central research laboratories of the reorganized Science and Engineering Research Council (SERC) - the Rutherford Appleton Laboratory and the Daresbury Laboratory - in order to boost declining morale among staff.

Both the Royal Academy of Engineering and the Institute of Physics, in separate submissions to the government on the reorganization of the laboratories, express strong opposition to either laboratory being sold off to the private sector. Both suggest that they should be set up as a single "nondepartmental public body' (NDPB) under the Office of Science and Technology.

But each of the two bodies also takes the government to task for delays in implementing such a change, which was first proposed last summer by Sir David Phillips, then chairman of the Advisory Board for the Research Councils.

Clive Foxell, president of the Institute of Physics, says in a letter to William Waldegrave, the cabinet minister responsible for science, that it is "inexcusable" that no decision has yet been reached by the government. "Morale has suffered," says Foxell. "Too much of the laboratory's management time has been expended on dealing with this issue rather than on future activities within the laboratories."

The future of the Rutherford Appleton and Daresbury Laboratories has been up in the air ever since last year's government white paper (policy document) which led to the break up of the SERC this week (1 April). Early agreement was reached on combining the two laboratories into a single administrative unit operating under a single director, but the government has not yet decided how far they should be exposed to market-place competition.

Earlier this year, a report from management consultants KPMG gave the laboratories high marks for the value of the services that they provide to universities throughout Britain and abroad, and concluded that privatization "would not be a sensible option".

Both the Royal Academy of Engineering and the Institute of Physics support this view. "We must ensure that unnecessary change does not take place for the sake of it," Sir William Barlow, the president of the academy, said last week.

One alternative to setting up the combined laboratories as an NDPB would be to hand over management to a consortium of universities, as is common practice in the United States. But the academy considers it "questionable whether UK universities have relevant experience or even the decisionmaking mechanisms to set up such a system".

Both institutions say that the two laboratories should be encouraged to increase the amount of contract research carried out for private industry, and that their role is likely to increase in importance as university departments seek the economies of scale offered by centralized research facilities. But both also support the government's desire to encourage greater competition between the providers of publicly funded research services (while warning against the application of this principle to basic research).

In a separate comment to Waldegrave, the Royal Society also opposes privatization.

David Dickson 